\section{Response to: 'Can IL-1 be used as a target for osteoarthritis?' by Cheng et al}

We thank Cheng, Tian and Zhang ${ }^{1}$ for their interest in our $\operatorname{article}^{2}$ that showed that targeting interleukin (IL)- $1 \alpha$ and IL-1 $\beta$ with lutikizumab did not significantly improve clinical and imaging outcomes in patients with inflammatory erosive hand osteoarthritis (HOA). The results of the study were indeed disappointing and, appropriately, should stimulate discussion about the role of IL-1 in osteoarthritis.

In our trial, levels of IL-1 were significantly reduced in subjects with erosive HOA and moderate to severe inflammation indicated by joint swelling, joint pain and synovitis. ${ }^{1}$ Although levels of IL-1 were not measured after week 4 of treatment, other biomarkers (eg, neutrophils, high-sensitivity C-reactive protein and matrix metalloproteinase-degraded collagen type 1) were monitored for 26 weeks and also exhibited significant reductions with lutikizumab compared with placebo (figure 3 in the original article). Modest differences between lutikizumab and placebo were observed for several other biomarkers through week 26 (online supplementary table 6 in the original article), although additional biomarkers showed no such effects. This suggests that the pharmacodynamic effects of lutikizumab were not limited to short-term changes in concentrations of IL-1 but rather were consistent with the long-term neutralisation of IL- $1 \alpha$ and IL-1 $\beta$.

We agree that assessing patient-rated, quality-of-life (QoL) and functional outcomes in clinical trials is important to understand fully the potential impact of the therapy under consideration. Regarding patient global assessment, health-related QoL and functional outcomes in our study, we refer Chen et al and other readers to supplementary table 4 , which is available online at the journal's website and which is called out in the original article as follows: "Other efficacy outcomes (pain, stiffness, grip strength and patient-reported outcomes) were also not different between the placebo and lutikizumab groups (online supplementary table 4)". In line with the main results of the study, there were no significant differences between lutikizumab and placebo in changes from baseline to week 26 for any of the endpoints described in online supplementary table 4, including Australian/Canadian Osteoarthritis Hand Index Stiffness scale, subject assessment of hand pain intensity, patient global assessment, grip strength of the index hand, 36-item short-form health survey, Patient Reported Outcomes Measurement Information System Physical Function Questionnaire, Michigan Hand Outcomes Questionnaire and Functional Index for Hand Osteoarthritis.
Finally, similar to our results, a recently published article about a randomised, placebo-controlled, double-blind phase II study of lutikizumab in subjects with knee osteoarthritis demonstrated no benefit of active treatment compared with placebo. ${ }^{3}$ Taken together, these two studies of lutikizumab call into question the strategy of targeting IL-1 in patients with osteoarthritis.

\section{Margreet Kloppenburg, ${ }^{1}$ Marc Levesque ${ }^{2}$}

${ }^{1}$ Rheumatology, LUMC, Leiden, The Netherlands

${ }^{2}$ Immunology Development, AbbVie, North Chicago, Illinois, USA

Correspondence to Professor Margreet Kloppenburg, Rheumatology, LUMC, Leiden 2300 RC, Netherlands; g.kloppenburg@lumc.nl

Handling editor Josef S Smolen

Contributors MK: concept, revising. ML: concept, writing, revising.

Funding AbbVie funded the study (NCT02384538). AbbVie funded medical writing support, which was provided by Michael I Theisen, PhD, of Complete Publication Solutions (North Wales, Pennsylvania, USA), a CHC Group company.

Competing interests MK has received grant/research support from Pfizer and been a consultant for AbbVie, GlaxoSmithKline, Merck, Pfizer and Levicept. ML is an employee of AbbVie and may own AbbVie stock and/or stock options.

Patient consent for publication Not required.

Provenance and peer review Commissioned; internally peer reviewed.

(C) Author(s) (or their employer(s)) 2020. No commercial re-use. See rights and permissions. Published by BMJ.

\section{Check for updates}

To cite Kloppenburg M, Levesque M. Ann Rheum Dis 2020;79:e89.

Received 12 June 2019

Accepted 15 June 2019

Published Online First 27 June 2019

\section{(5) Linked}

- http://dx.doi.org/10.1136/annrheumdis-2019-215513

Ann Rheum Dis 2020;79:e89. doi:10.1136/annrheumdis-2019-215612

\section{REFERENCES}

1 Cheng C, Tian J, Zhang F. Can IL-1 be used as a target for osteoarthritis? Ann Rheum Dis 2020;79:e88.

2 Kloppenburg M, Peterfy C, Haugen IK, et al. Phase IIA, placebo-controlled, randomised study of lutikizumab, an anti-interleukin- $1 \alpha$ and anti-interleukin- $1 \beta$ dual variable domain immunoglobulin, in patients with erosive hand osteoarthritis. Ann Rheum Dis 2019;78:413-20.

3 Fleischmann RM, Bliddal H, Blanco FJ, et al. A phase II trial of lutikizumab, an antiinterleukin- $1 \alpha / \beta$ dual variable domain immunoglobulin, in knee osteoarthritis patients with synovitis. Arthritis Rheumatol 2019;58. 